\title{
Is It Possible To Govern Foreign Investments? Balancing Between Klondike And Poltava
}

Olga Golubeva, Ph.D., Södertörn University, Sweden

\begin{abstract}
FDI (foreign direct investment) of Swedbank in Ukraine is an example of unsuccessful investment in transition economies. The Case Study is presented in relation with Swedbank's internationalization strategy and rapidly changing investment environment in transition economies and globally. Learning objectives include helping students to develop analytical skills in order to understand how political, economic, financial and social factors effect internalization strategy through FDI. The Case Study should help students to understand the importance of an appropriate long-term strategy of a firm entering transition economies, understand the investment environment of a foreign country and choose the best course of action for a distressed firm considering alternative scenarios. Lessons learned from the Case Study can be beneficial for students studying international business, but also for future decision-makers that would be acting in complex environments under rapidly changing situations. The author developed the Case from secondary sources: Swedbank's annual reports and press-releases, information published by multilateral organizations and government agencies, research from investment banking houses and reputable news agencies. This Case is written solely for educational purposes and is not intended to analyze successful or unsuccessful internalization strategy through FDI in transition economies.
\end{abstract}

Keywords: Case Study; Internalization Strategy; FDI (Foreign Direct Investments); Transition Economies

\section{INTRODUCTION}

n July 2007, Swedbank acquired the Ukrainian bank TAS from a local oligarch Sergej Tigipko for about
800 million USD (Swedbank, 2007, July 9). Growth prospects were enormous and many foreign banks were streaming to Ukraine, an investment Klondike at that time. Only 5 years later since arrival to Ukraine, in April 2013, Swedbank informed the market that it would totally discontinue its operations in Ukraine (Swedbank, 2013, April 1). Some journalists compared this Swedbank's investment with a historical loss of the Swedish army during Poltava battle. How it could go so wrong so quickly? Is it possible to govern foreign investments? Or is it random probability that determines the outcome of acquisitions abroad?

\section{SWEDBANK'S INTERNALIZATION STRATEGY IN BALTIC COUNTRIES, RUSSIA \& UKRAINE}

Swedbank, one of the four major Swedish banks, has its roots in the Swedish savings bank tradition dating back to 1820. In 2014 Swedbank had about 8 million private customers, more than 600,000 companies and organizations, over 14,000 employees and around 500 branches. Swedbank's total income in 2014 exceeded 5 billion USD, annual profit was approximately 2.15 billion USD, total assets were 274 billion USD and lending to the public amounted to 171 billion USD ${ }^{1}$ (Swedbank, Annual report 2014). Swedbank is used to apply a traditional banking model focused on close customer relationships and personal advice to private individuals as well as small- and medium-sized companies.

When reforms in Central and Eastern Europe (CEE) took place, the interest was turned to the new emerging markets, geographically closely located to Sweden - the Baltic countries and Russia, often labeled as transition economies. The Baltic economies had experienced an extended period of economic growth. Average annual real GDP growth was $8 \%$ in 2000-2006, which made the Baltic countries the fastest-growing region in the European 
Union (EU) (Swedbank, Annual report 2007). Among the key reasons for the strong growth was the Baltics' inclusion in the EU in 2004, which led to harmonization of legislation and state institutions with the rest of Europe. At the same time, the three Baltic countries were harvesting the fruits of the radical reforms implemented in the 1990s. All three ranked high in terms of economic freedom, transparency and innovation. Rapid growth in the Baltic countries was also fueled by the consumer spending, which has been driven by higher disposable incomes and available credit from abroad. During that time, the Baltic countries were in an expansive period of the credit cycle. Mortgage loans represented approximately $20-30 \%$ of GDP in the Baltic countries, compared with $40-60 \%$ in the EU. Russia also enjoyed strong GDP growth, approximately 6.6\% in 2006 (Swedbank, Annual report 2007). The financial sector in Russia, both the corporate and private markets, developed well.

A large and rapidly growing Baltic and Russian financial markets created opportunities for foreign investors. In 1999, Swedbank obtained over a 50\% stake in Hansabank, the leading financial institution in the Baltic countries (Swedbank, Annual report 1999). In 2002, a leasing company Hansa Leasing Russia was established in Russia (Swedbank, Annual report 2002). And, finally, in 2005 Hansabank successfully completed the acquisition of the Moscow-based OAO Kvest bank in Russia. The same year Swedbank purchased 100\% of Hansabank's shares and Hansabank become entirely part of Swedbank Group (Swedbank, Annual report 2005). Estonia, Lithuania and Latvia started to account for a growing share of Swedbank's earnings. In 2008, for example, Swedish banking with $75 \%$ of Swedbank's total lending generated only $52 \%$ of the total profit, while Baltic banking with $17 \%$ of lending generated 25\% of total Swedbank's profit (Swedbank, Annual report 2008).

Swedbank's lending in the Baltics in local currency grew 59\% in 2006 and 33\% in 2007 (Swedbank, Annual report 2007). Russia also started to roll out with new branches being opened in St. Petersburg and Kaliningrad (besides Moscow) and retail banking services being launched in addition to corporate banking. In 2007, Swedbank expected that the nominal annual growth in Baltics and Russia in the next three to five years would be about $10 \%$ (Swedbank, Annual report 2007). The financial sector would grow even faster, as penetration for banking products in the Baltic countries and Russia was still low.

The banking market in Sweden is a mature one, characterized by a tough competition between banks. A question emerged, if Swedbank's strategy should be changed from being primarily a Swedish bank to an international banking group with Swedish roots. "Swedbank's aim is to grow. European countries with lower than-average GDP per capita and penetration of financial services, particularly in Eastern Europe, are considered to offer the greatest opportunities for long-term growth", - stated Swedbank in the Annual report for 2007. Stable earnings in Sweden and strong balance sheet could support such a growing internationalization strategy.

Ukraine, with its 47 million populations, was one of the countries that experienced the greatest economic decline after the fall of communism, by 60 percent between 1990 and 1999. However, between 2000 and 2006, GDP rose $52 \%$, or $7.4 \%$ per year (Swedbank, Annual report 2007). Household consumption was growing strongly thanks to a robust job market and falling unemployment as well as double-digit increases in real disposable income. From the early days of the Orange Revolution in 2004 to the market's peak at the end of 2007, the Ukrainian First Stock Trade System index boasted an impressive increase exceeding 500\%. In 2007, the Ukrainian stock market was ranked the best performing stock market in the world, which explained the interest of foreign financial investors (Zelenyuk, 2007).

Rapid credit growth in Ukraine was contributing to higher spending and investments. Credit growth reached $76 \%$ on an annual basis in July 2007. Bank loans accounted for over $15 \%$ of financing for corporate investments, compared with $8 \%$ in 2003-2004. However, forward-looking potential was attractive: GDP per capita in Ukraine was only $25 \%$ of the OECD average, leaving plenty of room for a "catch-up" growth (Swedbank, Annual report 2007).

In early July 2007, Swedbank acquired the Ukrainian bank TAS-Kommerzbank with its subsidiary TAS-Investbank from the local oligarch Sergej Tigipko for about 800 million USD. An additional payment of up to 250 million USD should be payable in three years, subject to growth performance (Swedbank, 2007, July 9). Swedbank's acquisition of TAS-Kommertzbank and TAS-Investbank was part of the internationalization strategy in growth outside the group's home markets. After acquisition in Ukraine, the amount of Russian-speaking employees at Swedbank Group (including Baltic countries) had exceeded the amount of Swedish-speaking persons. 
According to unaudited IFRS Management Accounts, TAS had total assets of 1,142 million USD and loans of 834 million USD as per 2006 year-end. Profit for 2006 amounted to modest 10 million USD, reflecting heavy investments in TAS' branch network expansion. At year-end 2007, Swedbank in Ukraine had 3,433 employees and more than 125,000 private customers and 16,000 corporate customers. The head office situated in Kiev, and there were 191 more offices around Ukraine, an increase from 95 offices in 2006 (Swedbank, 2007, February 7).

Lehman Brothers acted as a financial advisor to Swedbank (Forsberg, 2009). In 2006 TAS had equity of USD 127 million (Swedbank, 2007, February 7). The purchased price of 800 million USD paid by Swedbank was not a cheap deal even in 2007. Goodwill, i.e. difference between net worth of TAS banks and the acquisition price was about 673 million USD. According to Swedbank, goodwill was justified by long-term growth possibilities in the Ukrainian banking sector. "Through Swedbank in the Ukraine, we are now one of the 15 largest banks in the country. The Ukrainian banking market is still in its infancy, but substantial growth is expected to continue for many years to come", - commented Jan Lidén, CEO of Swedbank at that time in the press-release from $9^{\text {th }}$ of July 2007.

Swedbank's own risk department was asked to prepare a report summarizing risks associated with the FDI in the Ukrainian bank (Forsberg, 2009). Report highlighted both political and economic risks associated with such an investment, including internal political instability and on-going conflict between Ukraine and Russia regarding gas supply and transmission. Besides, the report pointed on the underdeveloped legal system, risk of devaluation of hryvna (UAH), Ukrainian national currency, and corruption. On the anti-corruption organization Transparency International's list of 168 countries, Ukraine is currently on a 130th place. ${ }^{2}$ These warning conclusions, however, could not stop the acquisition.

An audit company Ernst \& Young performed the so called 'due diligence' report in connection with the acquisition of TAS banks (Forsberg, 2009). Ernst \& Young found that TAS, which was owned by Ukrainian oligarch Sergej Tigipko, provided loans to different companies belonging to Tigipko's own business imperium. Swedbank, therefore, through acquisition of TAS banks, would inherit loans related to Tigipko's companies. One might question if the Western investor should buy a bank with dependency on the business of the former owner. On the other hand, many banks in transition economies were founded as a 'pocket banks' of local oligarchs servicing their financial needs. The TAS' dependency on companies belonging to Tigipko's imperium was not a unique, but a standard practice in the Ukrainian business environment.

An impressive profit exceeding 2.3 billion USD earned by Swedbank in 2007 (among others, due to contribution from the Baltic countries) was a good supporting argument for the expansion strategy (Swedbank, Annual report 2007). And Swedbank saw its leading position in the Baltic region as a springboard to the larger Ukrainian economy. "The current situation in Ukraine is similar to what we saw in the Baltics for 8-10 years ago. Possibilities are high in future", - explained Carl Eric Stallberg, at that time the Chairman of the Board of Swedbank AB, to Swedish business newspaper "Dagens industi" on the $7^{\text {th }}$ of February 2007.

Acquisition of TAS banks was finally approved by the Board of Directors of Swedbank AB, and no objections from the members of the Board were reported (Swedbank, Annual report 2007).

Swedbank was not alone to be interested in the Ukrainian banking market, often described as an investment Klondike at that time. Swedish SEB was the first to establish in Ukraine via purchase of $90 \%$ of Agio Bank for 29 million USD. In 2007 SEB bought another bank, Factorial, with 53 branches and assets of 452 million USD for the price of approximately 116 million USD (Realtid Näringsliv, 2007). SEB's establishment in Ukraine was in line with strategy to grow in the Eastern Europe. Even East Capital, Swedish assets' management company, was drawn to the banking sector in Ukraine. In August 2006 East Capital purchased about 7\% of Nadra bank for approximately 48 million USD; and in January 2008 almost 10\% of Pivdennyi Bank was bought by East Capital for approximately 76 million USD. The P/BV (Price for Book Value ratio) at purchase was 3.6 for Nadra Bank and 4.5 - for Pivdennyi Bank (Öman Fondkomission, 2008).

Swedish banks were accompanied by other foreign banks. In 2007, at least 10 Ukrainian banks found themselves in the hands of foreign owners (Tigipko, 2008; Hrebeniuk, 2012). Good deals turned Ukrainian oligarchs into dollar billionaires overnight - mostly because of the overheated banking sector. For this purpose, owners of Ukrainian 
banks rapidly expanded regional network and volume of assets. Risks, performance and strategy were often subordinated to growth and marketing targets. The main drive for local oligarchs was to get a good price to be paid by foreign investors.

To justify the gargantuan prices, the purchased bank was expected to provide sustainable rapid growth in assets at $10-12 \%$ annually, about $20 \%$ annual ROE (return on equity) and equity value growth in the range of $13-16 \%$ annually (Hrebeniuk, 2012). That was an approximate financial target of foreign investors regarding their acquisitions in the Ukrainian banking sector at that time.

According to the National Bank of Ukraine (NBU), only $7.7 \%$ of the cumulative FDI into the share capital of Ukrainian companies went to the financial sector in 2004. In 2008, however, the figure was almost $30 \%$. Over 20062008 , nearly $42 \%$ of 26 billion USD of FDI in Ukraine went to the financial sector as foreign interest in Ukrainian banks peaked (Hrebeniuk, 2012).

There have been several positive impacts on the Ukrainian economy from European banking groups' FDI inflow. Foreign banks introduced the new standards of corporate governance, risk management and customer service. Besides, most European banking groups are public companies, their operations closely watched by shareholders and transparency of operations is high. The statements of their Ukrainian subsidiaries, therefore, started to be prepared and audited under international financial reporting standards (IFRS) accounting rules, which increased the transparency of the Ukrainian banking sector.

In late 2007, a strategy for Ukraine was formulated by Swedbank to further expand in the corporate market by offering companies an improved range of financial products as well as in private segments including the growing middle class and the mass market. Substantial volume growth and branch expansion were declared to be strategic cornerstones. It was decided that Swedbank in Ukraine should advance from $15^{\text {th }}$ place to top ten banks in the country (Swedbank, Annual report 2007).

Swedbank acquired two banks from Sergej Tigipko - TAS-Kommerzbank and TAS-Investbank. These two banks were re-named to Opened Joint Stock Company (OJSC) Swedbank and Closed Joint Stock Company (CJSC) Swedbank Invest respectively (Swedbank, Annual report 2007). The smaller bank, CJSC Swedbank Invest, had a niche offering loans primarily for investment projects and high net worth individuals, while the larger OJSC Swedbank was a universal bank. However, the banks' product offerings partly overlap and banks even compete with each other for customers and projects. It was decided, however, to continue to run these two banks as separate units.

It was also agreed that TAS' former owner, Sergej Tigipko, would continue to act as CEO and would have overall responsibility for the bank's business and development. Mr. Tigipko at that time had over 14 years of top level banking experience, including top positions as the Governor of Ukraine's Central Bank as well as Minister of Economy and Vice Prime Minister (Swedbank, 2007, February 7; Waltersson, 2009). In connection with acquisition, it was agreed with Tigipko about additional payment of up to 250 million USD that could be payable in three years, subject to growth performance. Top management of TAS banks remained and continued to work for Swedbank (Swedbank, 2007, July 9).

\section{GLOBAL FINANCIAL CRISES AND ITS IMPACT ON SWEDBANK}

During 2000s, the global economy was stimulated by low interest rates, rising asset prices and credit expansion. At the same time, imbalances increased and debt levels rose to ever higher levels in both OECD countries and transition economies. 2008 saw the start of the most serious international financial crisis since the Great Depression of the 1930s. It resulted in the threat of collapse of large financial institutions, the bailout of banks by national governments, and downturns in stock markets around the world. In many countries, the housing market also suffered resulting in the subprime mortgage crisis, reintroducing the world to an era of bank failures, a credit crunch, private defaults and massive layoffs. The active phase of the crisis, which manifested as a liquidity crisis, can be dated from August 9, 2007, when BNP Paribas terminated withdrawals from three hedge funds citing a 'complete evaporation of liquidity' (Gangahar and Jones, 2007). In March 2008, the Federal Reserve Bank of New York provided an emergency loan to The Bear Stearns, a New York based global investment bank, try to avert a collapse of the 
company. However, Bear Stearns could not be saved and was sold to JP Morgan Chase (Board of Governors of the Federal Reserve System, 2013). The collapse of the company was a prelude to the risk management meltdown of the investment banking industry.

On September 15, 2008, Lehman Brothers, the fourth-largest investment bank in the US, filed for Chapter 11 bankruptcy protection following drastic losses in its stock and devaluation of its assets by credit rating agencies (CNBC, 2008). Swedbank was exposed to Lehman Brothers through some loans, but fortunately they were secured by real estates located in the US (Swedbank, 2008, October 7; Almgren, 2008, September 25). It is interesting to note that Lehman Brothers acted as a financial advisor to Swedbank in their acquisition of TAS banks in Ukraine. A downturn in economic activity started to lead to the 2008-2012' global recession.

Strong credit growth in the Baltic countries and interest rates that were too low relative to economic growth had begun to lead to an imbalance in prices, which was particularly noticeable in the real estate market. During 2007, when the real estate bubble burst after financing terms tightened, it started to be obvious that the rapid growth in the Baltic countries was not sustainable. The current account deficit, which had swelled in pace with rapidly growing imports, reached $20-30 \%$ of GDP in the Baltic countries. In December 2008, inflation was $7 \%$ in Estonia and $8.5 \%$ in Lithuania. Latvia's inflation rate was $10.5 \%$ in December 2008, declined from slightly over $17 \%$ in mid-2008. In 2008, Latvia's GDP shrank by minus $4.6 \%$ and Estonia's by minus 3.6\%, while Lithuania's slowed down to $3 \%$ (Swedbank, Annual report 2008). As the crisis swept across CEE, the economic reversal intensified: Estonia's GDP dropped by minus $16.2 \%$ year-on-year, Latvia's by minus $19.6 \%$ and Lithuania's by minus $16.8 \%$. By mid-2009, all three countries experienced one of the deepest recessions in the world (Swedbank, Annual report 2009).

Due to the growing global financial crisis, the small but open economy of Ukraine also started to face turbulence. From Q4 2008 until Q1 2009, the economic situation in Ukraine became intolerable. The local currency declined from UAH 5 to a low of 9.5 to the USD before stabilizing at around 8 to the USD. GDP declined by a ruinous $15 \%$ during the whole of 2009 and the stock market, by the end of Q1 2009, had given up all of its gains of the previous 3 years and returned to pre-Orange Revolution levels (Swedbank, Annual report 2009). Demand for Ukrainian production, especially metals, fell in connection with the global recession, and external capital flows essentially came to a halt. Since the debts of domestic banks were largely denominated in foreign currency, depreciation of UAH led to severe banking crises.

At the same time, the Ukrainian economy was weighed down by a long-standing political crisis, which was delaying required structural reforms. In November 2008, the International Monetary Fund (IMF) offered help and approved a Stand-By Arrangement for 16.4 billion USD to stabilize the economy of Ukraine (IMF, 2008, November 5).

During 2008, Swedbank started to be affected by rapidly changing macroeconomic conditions, particularly in the Baltic countries and Ukraine, where Swedbank operated. Lending growth in the Baltic countries slowed from 33\% in 2007 to $6 \%$ in 2008. Loan losses increased to 230 million USD. Although the share of impaired loans was only slightly over $2 \%$, it was 5 times higher than in the previous year (Swedbank, Annual report 2008). It became obvious that Swedbank should revise the strategy in the Baltics and Ukraine and break the loan growth. The expansion continued too long and employees were rewarded for growth.

For 2009, Swedbank's profit before credit impairments for the Baltic countries was 630 million USD. Credit impairments for Baltic banking, however, reached 2 billion USD. Profit in Ukraine for 2009 was about 68 million USD, while credit impairments of 890 million USD accompanied with a goodwill' depreciation resulted in an operating loss of 1 billion USD. For comparison, operating profit for the Swedish banking' business area during 2009 reached 1.1 billion USD while Swedbank Markets, an investment banking unit, generated profit of 452 million USD. Profit earned by the 'Swedish part' of the bank and its investment unit was not enough to off-set losses in Baltics and Ukraine. In 2009 Swedbank Group showed a total loss exceeding 1.3 billion USD (Swedbank, Annual report 2009).

Swedbank's share development at that time reflected worries and concerns from investors and external community. During 2008, the OMX Stockholm 30 Index fell by 37 percent and the price of the Swedbank Class A share fell by 
approximately 75 percent. The share reached a high for the year of SEK 182, on 3 January, and a low of SEK 42, on 22 December. $^{3}$

Swedbank started to face one of the biggest challenges in the bank's history since 1820s. It was a question of survival, and external help was needed to overcome the crises. In October 2008, Riksbank (Central Bank of Sweden) initiated a series of liquidity measures, lending money to Swedish banks in order to avoid a more serious credit crunch. The government decided at the same time to introduce a financial stability plan, part of which included a guarantee programme to refinance Swedish banks. The Swedish National Debt Office granted Swedbank's application to participate in the Swedish state's guarantee programme (Swedbank, Annual report 2008).

During 2008 and 2009, Swedbank executed two additional rights issues that gave Swedbank about 3.7 billion USD (Swedbank, Annual reports 2008 and 2009). The rationale behind the rights issue was to take proactive and decisive action in this volatile and uncertain market environment. An important objective of the rights issue was to gradually leave the guarantee programme.

Several projects in 2008 and 2009 at Swedbank centered on further enhancing the efficiency and quality of credit processes, from credit assessment to distressed debt management. In general, more stringent lending criteria have been imposed prioritizing to identify and target customers with strong loan servicing ratios. In addition, more resources were assigned to the team responsible for handling distressed debt.

Being a traditional Swedish bank, Swedbank had limited experience to govern its international operations. It was decided to consolidate all operations outside Swedbank's home markets in the strategic business area International Banking. International Banking's organizational structure was settled on 1 July 2008 to improve support for international operations, especially in steering and risk control (Swedbank, Annual report 2008).

Swedbank also started to change top management. The new President and CEO Michael Wolf took up his new position on 1 March 2009 (Swedbank, Annual report 2009). Since that time, many key managers were gradually replaced. The management team was strengthened with increased focus on risk management, communication and implementation of a common business model for the bank's domestic and international markets.

The reduction of the Group's lending outside Sweden was one of the measures introduced in 2009 in order to reduce risks in the Swedbank Group. At the end of 2009, for example, the share of lending in the Baltic countries decreased to 12 percent of the total lending, down from 16 percent in 2008. The share in Ukraine and Russia declined to 1 percent, compared to 3 percent in 2008 (Swedbank, Annual report 2009).

When the financial crisis reached Ukraine, the problems of two Ukrainian subsidiaries of Swedbank became obvious and logical - the consequences of the mass distribution of loans, including those in the overheated real estate market.

For 2008, Swedbank Ukraine's loans were 2.4 billion USD and gross impaired loans amounted to almost 128 million USD (Swedbank, Annual report 2008). For 2009, loan portfolio in Ukraine was down to approximately 1.2 billion USD, while gross impaired loans exceeded 1 billion USD (Swedbank, Annual report 2009). Performing portfolio, generating income for Swedbank Ukraine, was shrinking while non-performing (impaired portfolio) had grown, requiring more and more provisioning for bad debts.

Swedbank Ukraine's rating was cut by the rating agency Fitch to 'E'-level on January, 29th, 2009. Fitch's individual rating ' $E$ ' indicated that a bank had very serious problems, which either required or would likely to require external support. Fitch Ratings explained that it downgraded Swedbank Ukraine to reflect the bank's increased credit risk. According to Fitch, Swedbank's loan portfolio grew $170 \%$ over nine months of 2008 , which was at very high speed taking into account the turbulent market situation. Besides, Swedbank had a high concentration of foreign-currency loans, higher than the majority of its peer banks. At the end of 2008 , about $80 \%$ of Swedbank's total loans in Ukraine were in foreign currency (Concorde Capital, 2009, January 29). 
Cheap funding available from Sweden in USD, aimed to boost the growth strategy in Ukraine, had a negative impact after UAH depreciated by $60 \%$. Such depreciation was especially suffered by private persons and companies that took loans in hard currency without having matching revenues in the same currency.

Due to uncertainty on the market and global turbulence, Swedbank started to revise the growth targets downward. In 2008 , it was decided that at least throughout 2009, the operations would focus on quality control rather than growth. New lending was almost abolished and Swedbank placed high quality requirements on new lending to small and medium-sized companies.

In order to improve governance, risk management, transparency and achieve economies of scale, Swedbank announced in June 2009 that it would merge two Ukrainian banks acquired by Swedbank - OJSC Swedbank and CJSC Swedbank Invest (Swedbank, Annual report 2009). According to the NBU, OJSC Swedbank was Ukraine's $15^{\text {th }}$ largest bank by assets (15 billion UAH) at the time of a merger, and Swedbank-Invest - number $30^{\text {th }}$ (with assets of 5.3 billion $\mathrm{UAH})$.

Following severe losses and changes in expectations for Ukraine, operations were adapted to lower business volumes. The number of branches has been reduced from over 200 in early 2009 to 92 at year-end 2010. The number of employees was reduced during the same year by 1326 people to 1554 (Swedbank, Annual report 2010).

Swedbank's special risk team for financial restructuring and recovery, FR\&R, was established in Ukraine. The team was going through all sizable impaired loans, helping the bank either to restructure or to recover the loans. 'Restructuring' and 'recovery' became the major daily concepts replacing previously applied 'growth strategy' and 'market share targets'. Hundreds of corporate loans and thousands of private credits had been worked out, which finally contributed to the better outcome. As a result, restructured loans in Swedbank Ukraine exceeded 288 million USD in 2009 (Swedbank, Annual report 2009).

Although Swedbank started to adjust the strategy to the worsening market conditions, the move was obviously not enough quick to reflect the dramatic changes in the business environment. At the same time, Swedbank discovered that protection of creditor rights was extremely weak due to inadequate legislation and high corruption level.

Swedbank decided to write off the remaining goodwill in Ukrainian investment in 2009 (Swedbank, Annual report 2009). Goodwill of approximately 673 million USD gained by Swedbank as a result of acquisition of TAS banks disappeared in 2 years after investment was made (Waltersson, 2009). Investment banking company BG Capital Research estimated that Swedbank also injected about 450 million USD in equity and subordinated debt into its Ukrainian subsidiary in order to survive the crises situation (Vavryshchuk, 2010).

According to NBU, the exposure to a single customer at the Ukrainian banks should not exceed 25\% of the bank's capital base, the same rules that apply in Sweden. Swedbank Ukraine inherited loans to Sergei Tigipko's companies exceeding 160 million USD, which resulted in breaking the rules of NBU about lending limitation to a single customer (Avanza research, 2009; Forsberg 2009). In order to comply with NBU regulations, Swedbank either should minimize the exposure against Tigipko's companies or inject additional capital.

During financial crises, the difference between European and Ukrainian banks had escalated. The interests of owners of European banks lie in the orbit of the banking business. It is hard to imagine a situation where a parent bank based in Europe instructs its Ukrainian subsidiary to issue a loan to a specific company or to overlook the rules for issuing loans to one borrower or associated entities. Unlike them, most bank owners in Ukraine have other primary businesses and use their banks as donors more than anything else in times of crisis. Officially, they comply with the NBU's restriction on lending more than $25 \%$ of the regulatory capital to one borrower. Yet, some analysts suggest that the real level of insider lending in some captive banks may exceed $50 \%$ of the total loan portfolio (Hrebeniuk, 2012). The regulatory authority does not monitor the entities of big business group owners deeply enough to determine this.

In Sweden, criticism was expressed by several external parties, including Aktiespararna, Swedish Shareholders Association. Aktiespararna questioned how such a big loan could be provided to a single borrower, who at the same 
time acted as a CEO of Swedbank Ukraine. Lending the substantial amount to a related party would be prohibited under the Swedish Corporate Governance Code, and this is the case for other European banks (Rolander, 2009). The fact that one billion Swedish krona was not loaned to Sergej Tigipko himself, but to his companies, was not enough to explain and justify the situation to auditors, investors, customers and Swedish public (Mellqvist, 2009).

In 2009, CEO of Swedbank Ukraine (and former owner of TAS banks) Sergey Tigipko resigned from his operational position. He was offered, however, the position of a member of the Council of Swedbank Ukraine (Hermele, 2009). The new CEO Reiner Müller-Hanke was appointed in Swedbank Ukraine (Swedbank, 2009, April 29). Reiner Müller-Hanke previously served as CEO of KMB BANK, owned by Intesa Sanpaolo, and hold several top management positions in the financial sector in Germany, Russia and South America. The famous Ukrainian banker and financial oligarch Tigipko was re-placed by a western style banker with broad international experience. The whole Tigipko's management team was gradually changed to enhance top management under crises.

In line with other prudent measures undertaken by Swedbank during Ukrainian crises, change of management from people, loyal to Ukrainian oligarch Tigipko, to western style top professionals, was a necessary step in execution of corporate governance. It was a lot of critic in press, however, that such change should occur much earlier.

Already in September 2011, Swedbank had altered its strategy for the Ukrainian market and started exit the retail segment in order to focus solely on the corporate customers. "The change is in line with our strategy to offer universal banking on our four home markets and have more focused offering in niche markets", - commented Swedbank in a press-release from $20^{\text {th }}$ of September 2011. The performing mortgage portfolio amounting to 275 million USD was sold to Ukrainian Delta Bank at the end of May 2012. In November 2012, the sale of the retail secured non-performing loans (NPL) in the amount of 229 million USD to collection company Ukrborg and Russian Alfa bank was finalized (Swedbank, Annual report 2012). Sales of the retail portfolio occurred with sufficient discounts reflecting limited interest of investors in the Ukrainian assets at that time.

Only 5 years later since arrival to Ukraine, in April 2013, Swedbank informed the market that it would totally discontinue its operations in Ukraine. A major part of the remaining portfolio was sold to a local oligarch - Mr. Mykola Lagun, the majority owner in the Ukrainian Delta Bank (Swedbank, 2013, April 1). Swedbank Ukraine was renamed to Omega Bank, which occupied the 59th place in the ranking of the NBU on assets at that time. It is interesting to note that the fourth biggest bank in Ukraine, Delta Bank, went bankrupt during 2015 after months of non-compliance, according to the National Bank of Ukraine. Two smaller banks in the Delta Banking group, including Omega Bank that was acquired from Swedbank, were categorized insolvent along with Delta Bank (RT News, 2015).

2013 would be known in Swedbank's history as a year when Swedbank sold its subsidiary in Ukraine. Besides, operations in Russia were discontinued. In 2014 Swedbank also winded down the Russian subsidiary, which resulted in a loss from discontinued operations of 29 million USD (Swedbank, Annual report 2014).

\section{SWEDBANK AND INVESTMENT CLIMATE IN UKRAINE: POST GLOBAL FINANCIAL CRISES}

In 2010 the global economy recovered more quickly than expected from the financial crisis. After major production losses in 2009, the Swedish and Baltic economies have begun to improve. The strongest recovery in 2010 was in Sweden, where GDP rose by over 5\%. Swedbank's profit amounted to 1 billion USD for 2010, an increase of 2.6 billion USD compared to 2009. The improvement was mainly due to significantly lower credit impairments in the Baltic countries, Russia and Ukraine (Swedbank, Annual report 2010). The profit for 2014 exceeded 2.1 billion USD, due to stable income, stable expenses and low credit impairments. The share of impaired loans was only 0.41 percent in 2014, which suggests that the credit quality in the loan portfolio is currently good (Swedbank, Annual report 2014).

The Board of Directors of Swedbank adopted new goals for the bank's risk appetite and risk tolerance, which serve as cornerstones to ensure that Swedbank remains a robust bank going forward. The new decentralized organization in Sweden was introduced by Swedbank, giving more decision-making power to managers working close to the clients. Decentralization should both improve customer satisfaction and allow for closer risk monitoring. 
Performance of Swedbank's share price reflected normalization of situation in the company. In 2013, the OMX Stockholm 30 Index rose by 21 per cent and OMX Stockholm Banks Index increased by 42 per cent. Swedbank's A share gained 43 per cent during the year. ${ }^{3}$

In line with other banks, Swedbank is focusing on structural changes undergoing in banking industry including broad usage of digital channels - telephone, internet and mobile. In addition to improvements for customers, digitalization creates opportunities for banks, which can profit from efficiency gains such as reduced use of cash in society. On the other hand, competition in banking increases as new niche players' stream into the industry offering loans and providing banking services.

"We want to be a modern and attractive bank in the future", - writes Swedbank in the Annual Report for 2013. Swedbank also plans to maintain a robust balance sheet that can withstand economic swings. Priorities for 2015 and nearest future include improvement of customer value and increase of efficiency (Swedbank, Annual report 2014).

The financial sector is currently undergoing significant change, including at a regulatory level within the EU. The annual stress tests of major Swedish banks conducted by the Riksbank and the Swedish Financial Supervisory Authority (SFSA) in 2014 showed Swedbank's resilience. During 2014, the Common Equity Tier 1 capital ratio increased to 21.2 per cent, which is a very high level (Swedbank, Annual report 2014).

The global recovery in 2014 was unbalanced. The US continued to grow, while the Eurozone was threatened by slower activity and deflation. Shaky global economic conditions could impact the relatively strong growth in Sweden and the Baltic countries. Increasing international competition and digitalization contribute to low Swedish inflation, which coupled with a low interest rate environment, is pinching bank profits and credit demand in the industrial sector. Urbanization and population growth, together with a shortage of housing construction in major Swedish cities, are driving credit demand in the real estate sector, but could mean even higher and more risky levels of household debt.

Credit demand in Swedbank's home remains uncertain. Swedbank's lending rose by modest 2.6\% in 2013; in Baltic Banking, the lending portfolio grew slightly in Estonia and Lithuania, but decreased in Latvia. The discontinuation of the Russian and Ukrainian operations reduced lending volume by 638 million USD in 2013 (Swedbank, Annual report 2013). During 2014, lending volumes grew to 171 billion USD, mainly attributable to raise in mortgage and acquisition of Sparbanken Öresund (Swedbank, Annual report 2014).

Sweden, Estonia, Latvia and Lithuania are Swedbank's home markets. To support customers' businesses, Swedbank also has operations in Norway, Finland, Denmark, the US, China and Luxembourg. In 2014 Swedbank decided to open a representative office in Johannesburg, South Africa, in order to explore business opportunities in the rapidly growing African market (Fond \& Bank, 2014, June 9). This is, however, a minor investment in an office with few employees.

Limited growth possibilities seem to remain a certain problem for Swedbank Group. The same challenge Swedbank faced before the global financial crises, when a step was taken to explore transition economies in Baltics, Russia and Ukraine.

FDI' stream into Ukraine stopped due to the global recession and the severe economic crisis affecting the country. State Statistics Service of Ukraine estimated that after partial recovery in 2010 (almost 24\% increase compared to 2009), the FDI flux dried again, declining from 4.13 billion USD in 2012 to 2.86 billion USD in 2013 (InterfaxUkraine, 2014).

Apart from the economic downturn, the inefficient and corrupted legal system, complexity of legislation and regulation, poor contract enforcement and poor governance constitute serious impediments to investment. This is so despite the fact that the country has its strengths: a large domestic market, proven agricultural potential, energy and mineral resources and a strategic geographic location which makes it a transit hub and a gate to Europe. Russia's annexation of Crimea, military operations in the Eastern Ukraine and escalation of the dispute between Ukraine's gas company Naftogaz and Gazprom of Russia led to a volatile political situation. 
The US and EU will probably encourage private companies to invest in Ukraine with new technologies, plants, factories, businesses and joint ventures, similar to what they already did in the 1990's with respect to the newly democratic countries in Eastern Europe. Such governmental encouragement will likely include direct grants, loan guarantees, insurance packages etc.

International Monetary Fund (IMF) approved a two-year Stand-By Arrangement for Ukraine at the end of April 2014. The arrangement of 17 billion USD should aim to restore macroeconomic stability, strengthen economic governance and transparency, and launch sound and sustainable economic growth (IMF, 2014, April 30). The program remains highly challenging and continues to hinge crucially on the assumption that the political situation will stabilize and authorities will strongly perform and strict to the planned reforms.

Foreign investors, however, need two critical conditions to invest in any emerging economy: political stability and economic predictability (Golubeva, 2001). These two conditions, unfortunately, are not in place in Ukraine in 2015. Political stability, self-sustained energy sector, comprehensive structural reforms, reducing corruption and improving business climate are needed to secure sustainable growth in Ukraine (USAID, 2010).

The financial sector is typically a barometer for changes in long-term investment expectations for Ukraine. The escalation of the European debt crisis in 2011-2012 and limited ability of European banks to support their unprofitable foreign subsidiaries have forced many of them to review their international strategies. High administrative pressure, ad hoc monetary regulation and corruption are obstacles making the operating environment extremely difficult and unpredictable even for the local Ukrainian banks. But this investment environment is completely non-transparent and not-understandable for foreigners. Besides, Fitch credit rating agency estimated that around 60 percent of lending in Ukraine is still done in foreign currency, therefore, miss-matching of currencies remains a problem. Banks have been also cautioned by the U.S. Treasury about potentially suspicious transfers of financial assets by Yanukovich or members of his inner circle (Davies, 2014, February 27).

Swedbank's decision to leave Ukraine was in line with many other foreign banks, they continue to clean up their balance sheets, shrink assets and search for potential buyers to exit the Ukrainian market. The large supply of banks of different sizes and portfolios, compared to demand, led to a considerable decline in the prices for banks. The prices dropped to a half of the equity, ten times less than in pre-crisis level during 2006-2007 (Rekrut, 2013). Despite that, the list of potential buyers is restricted to local oligarchs and, in the best case, some Russian banks.

The details on sale of Bank Forum from Commerzbank to Ukraine's Smart-Holding in 2012 were not disclosed. Ukrainian credit agency estimated, however, that the deal did not exceed 100-200 million USD, whereas Commerzbank had invested 1 billion USD in its Ukrainian daughter over the five years previous to sale. Kreditprompank, owned by a pool of foreign investors, was sold in 2012 for the symbolic amount of one dollar (!) to the Ukrainian businessman Mr. Mykola Lagun, who later also acquired Swedbank Ukraine (Rekrut, 2013). As mentioned earlier, Lagun's Delta Bank group became insolvent in 2015.

Since 2009, more and more European banks have left Ukraine, including ING Bank, Erste Bank, Home Credit Group, Credit Europe Bank, Societe Generale, Universal, Intesa Sanpaolo and Volksbank International (Hrebeniuk, 2012).

While other foreign lenders have cut their Ukraine exposure in five years since Lehman collapsed - to 20 percent of Ukraine banking sector assets in 2012 from 40 percent in 2008, Russian banks still account for 12 percent. In 2014 they had around 28 billion USD of exposure. Credit agencies have said that Russian banks should be able to cover losses with earnings or by getting government support (Reuters, 2014, February 26). However, even Russian banks almost seized new lending waiting for economic and political stabilization.

\section{CONCLUSIONS: LESSONS LEARNED?}

All in, Swedbank's investment in Ukraine can be ranked as one of the biggest investment failures that happened recently in Sweden. Some journalists compared this Swedbank's investment with a historical loss of the Swedish army during Poltava battle. How it could go so wrong so quickly? Is it possible to govern foreign investments? Or is it random probability that determines the outcome of acquisitions abroad? 
First of all, the global macroeconomic environment should be taken into consideration: year 2008 saw the start of the most serious international financial crisis since 1930s. At the same time, in 2007 we saw the highest peak of prices for Ukrainian banks.

"It is always easy to have comments in retrospect. Our investment in the Baltics in 1996 was strategically right then, and is right now, even if the countries are in trouble. The problems will be solved in time and there will be an interesting market in our region to remain active on”, - commented Swedbank's former Chairman Carl Eric Stålberg in an interview in 2008, just in the middle of the crises. He continued: "If you put everything in a retrospective, the timing on the Bank's entry into Ukraine could have been better... It is clear that it would have been fun to make this investment at a different time". At the same time, Stålberg emphasized that Ukrainian exposure accounted only for 1.5 percent of total lending (Joons, 2008).

But was it only the timing that was wrong? Swedbank's CEO Michael Wolf stressed in the Annual report for 2010 that "an important lesson from the financial crisis for Swedbank and other banks is to maintain full control over liquidity risks and ensure long-term financing, rather than maximise profitability from a short-term perspective". That is an important advice for banks when they considering FDI abroad.

Swedbank's experience is Ukraine also shows the importance of investment environment for decision-makers. As long as changes in the environment are smooth and predictable, the firm can use its knowledge to invest and reach an expected outcome. But the critical problem is when the environmental changes are not predictable, than the company should be able to adjust the strategy quickly to address the new non-expected challenges.

It is impossible to answer the question if the decisions to leave Ukraine by foreign banks, literally at any cost, are right or wrong. What is obvious, however, that foreign banks entering transition economies should not limit their business strategy to growth plans based upon cheap forex loans. They should have a long-term strategy operating through the economic cycle, including proper risk management in place, clear corporate governance procedure, well-functioning steering of foreign activities by owners and possibilities to quickly adapt to radical changes.

According to Business Sweden ${ }^{4}$, as of 2014, about 100 Swedish companies are established in Ukraine and approximately 400 - have close business relationships. Case of Swedbank in Ukraine might help not only to understand why certain firms choose to invest in Ukraine, but also why many others did not invest, and eventually, should not invest.

Former CEO Jan Lidén and Carl Eric Stålberg, Chairman of the Board of Swedbank AB at the time of crises, were often blamed for Swedbank's expensive internalization strategy. There are some indications, however, that the Swedish lending crisis in the transition economies was not a mistake of few managers, but a systemic error.

In 2006, Swedish banks had over 53.4 billion USD exposure to the Baltic states, which was also characterized by a mismatch of currencies. Mismatch of currencies happens if borrowing and lending amounts are distributed in different currencies. Already in 2006, Riksbank warned that this development could become unsustainable (Sveriges Riksbank, 2006). Sweden's financial supervisory authority (SFSA), Finansinspektionen, was aware of the risks, but took no countermeasures (Finansinspektionen, 2006).

Global financial crises highlighted the urgency of better control over the financial system. The EU's Capital Requirements Regulation (CRR) and Capital Requirements Directive IV (CRD IV), which contain new rules on capital adequacy, liquidity and corporate governance of banks, were approved in June 2013 and took effect on the $1^{\text {st }}$ of January 2014. The Swedish banking system is dependent on market funding, therefore, is sensitive to adverse developments abroad. As decided by SFSA, Swedish banks must hold larger capital and liquidity buffers than the minimum requirements imposed by the EU. A part of the new Swedish requirements is that banks must set aside extra capital of $1 \%$ from September 2015 in what is known as the countercyclical capital buffer. This figure should be raised to $1.5 \%$ from $27^{\text {th }}$ of June 2016, given the present economic conditions (Finansinspektionen, 2015, May 26). 
Although certain measures have been introduced, a lot of challenges remain to be addressed including high household debt in Sweden, risk weights ${ }^{5}$ for private mortgage loans and necessity to extend the maturity for the banks' funding (Finansinspektionen, 2014). It is also important to decide upon clear responsibility structure among the different bodies steering the banking system. The report from 2010 from Riksdagen, Swedish Parliament, pointed that there is no formal mechanism through which SFSA and Riksbank can discuss their opinions on stability issues (Goodhart and Rochet, 2011). There is also no formal mechanism for documenting these opinions, whether you agree or not. When Riksbank did have a concern about Swedish banks' exposure to transition economies, there is actually no clear documentation on SFSA's reaction about Riksbank's concern, and different people remember the situation in different ways. If (and when) the warning signals would appear, powerful action plan with clear responsibilities is needed, preventing the banking system from possible troubles.

Lessons learned from unsuccessful investment cases deserve attention from both researchers and practitioners. Serious work is required both on a company and on institutional level in Sweden in order to avoid future Poltava losses.

\section{AUTHOR BIOGRAPHY}

Olga Golubeva, Ph.D., is a senior lecturer at the Department of Business Administration, Södertörn University, is the contacting author. Dr. Golubeva's academic career is combined with over 18 years of management experience in the investment and corporate banking. Dr. Golubeva's research interests include international management, FDI, credit decisions and valuation of companies, financial and banking systems, Public-Private Partnership, sustainable investments. (Corresponding address: Dr. Olga Golubeva, Södertörn högskola, SE-14189 Huddinge, Sweden. olga.golubeva@sh.se)

\section{ACKNOWLEDGMENTS}

The author is grateful for helpful comments from the anonymous referees. Proofreading assistance of Dr. Alan Wood (UK) is acknowledged.

\section{REFERENCES}

Almgren, J. (2008, September 25). Swedbanks ordförande talar ut om krisen. Svenska Dagbladet. Retrieved from: http://www.svd.se/swedbanks-ordforande-talar-ut-om-krisen. (English translation: Chairman of the Board of Swedbank speaks about crises.)

Avanza research (2009, December 16). Lån i Ukraina kan kosta Swedbank banktillstånd. Retrieved from:

https://www.avanza.se/placera/redaktionellt/2009/12/16/lan-i-ukraina-kan-kosta-swedbank-banktillstand.html. (English translation: The loan in Ukraine can cost Swedbank a banking licence.)

Board of Governors of the Federal Reserve System. Bear Stearns, JPMorgan Chase, and Maiden Lane LLC. Last updated August 2, 2013, Retrieved from: http://www.federalreserve.gov/newsevents/reform_bearstearns.htm.

CNBC (2008, September 15). Lehman Brothers Files For Bankruptcy, Scrambles to Sell Key Business. Wall street in crisis - a CNBC special report. Retrieved from: http://www.cnbc.com/id/26708143

Concorde Capital (2009, January 29). Swedbank Ukraine's rating cut by Fitch to 'E'. Retrieved from: http://concorde.ua/en/research/daily/6621/\#sthash.BeUw524K.dpuf

Davies, M. (2014, February 27). Foreign banks in Ukraine face choice - hunker down or cut losses. Reuters news, Moscow.

Finansinspektionen (2006). Finanssektorns Stabilitet, 2006:14. Retrieved from: http://www.fi.se/Tillsyn/Rapporter/Listan/Finanssektorns-stabilitet-2006-200614/. (English translation: Financial sector's stability).

Finansinspektionen (2014, June 12). Household debt and bank's market funding - risks to stability. Press release. Retrieved from: http://www.fi.se/Folder-EN/Startpage/Press/Press-releases/Listan/Household-debt-and-banks-market-funding--risks-tostability/

Finansinspektionen, (2015, May 26). Proposal to amend the regulations on the countercyclical capital buffer. Press release. Retrieved from: http://www.fi.se/Folder-EN/Startpage/Supervision/Miscellaneous/Listan/Proposal-to-amend-theregulations-on-the-countercyclical-capital-buffer/

Fond \& Bank (2014, June 9). Swedbank öppnar kontor I Johannesburg. Retrieved from: http://www.fondochbank.se/Nyhetsarkivet/Fond--Bank-Online/2014/06/09/Swedbank-startar-kontor-i-Johannesburg/ (English translation: Swedbank opens a representative office in Johannesburg.) 
Forsberg, B. (2009, May 29). Guldjakten i Ukraina. Affärsvärlden. Retrieved from: http://www.affarsvarlden.se/hem/nyheter/article2591729.ece (English translation: Chasing gold in Ukraine.)

Gangahar, A. \& Jones, A.(2007, August 9). BNP Paribas investment funds hit by volatility. Financial times. Retrieved from: http://www.ft.com/intl/cms/s/0/9a4cabc4-464d-11dc-a3be-0000779fd2ac.html\#axzz3z2o8Zi14

Goodhart, C. and Rochet, J.-C. (2011). Utvärdering av Riksbankens penningpolitik och arbete med finansiell stabilitet 20052010, Rapport från Riksdagen 2010/11:RFR5, Riksdagstryckeriet, Stockholm. (English translation: Evaluation of Central Bank' of Sweden monetary policy and work with the financial stability in 2005-2010).

Golubeva, O. (2001). Foreign Investment Decision-Making in Transition Economies, PhD thesis, School of Business, Stockholm University, Sweden.

Hermele, B. (2009, April 29). Swedbank offrar Ukraina-chefen. Realtid. Retrieved from: http://www.realtid.se/ArticlePages/200904/29/20090429084605_Realtid591/20090429084605_Realtid591.dbp.asp. (English translation: Swedbank offers the Ukrainian Manager.)

Hrebeniuk, Y. (2012, October 23). Foreign Banks Flee Ukraine. The Ukrainian Week International Edition. Retrieved from: http://ukrainianweek.com/Economics/63007

IMF (2008, November 5). IMF Approves US\$16.4 Billion Stand-By Arrangement for Ukraine. Press Release No. 08/271. Retrieved from: https:/www.imf.org/external/np/sec/pr/2008/pr08271.htm

IMF (2014, April 30). Executive Board Approves 2-Year US\$17.01 Billion Stand-By Arrangement for Ukraine, US\$3.19 Billion for immediate Disbursement. Press Release No. 14/189. Retrieved from: https://www.imf.org/external/np/sec/pr/2014/pr14189.htm

Interfax-Ukraine (2014, February 17). Foreign direct investment in Ukraine in 2013 shrinks to $\$ 2.8$ billion. KyivPost. Retrieved from: http://www.kyivpost.com/content/business/foreign-direct-investment-in-ukraine-in-2013-shrinks-to-28-billion336936.html

Joons, A. (2008, December 4). Stålberg: Tajming i Ukraina kan diskuteras. Svd Näringsliv. Retrieved from: http://www.svd.se/stalberg-tajming-i-ukraina-kan-diskuteras (English translation: Stålberg: Time of entry into Ukraine can be discussed.)

Mellqvist, G. (2009, April 24). Swedbank-direktör har jättelån i Ukraina. Dagens industri. (English translation: Swedbank’s Director has huge loans in Ukraine".)

Öman Fondkomission (2008, May 7). East Capital Explorer. Financial Institutions Fund. Presentation. Retrieved from: http://www.ohman.se/upload/ALL/NewYorkPresentation/9\%20\%20East\%20Capital\%20Explorer\%20Financial.pdf

Realtid Näringsliv (2007, November 16). SEB Köper bank i Ukraina. Realtid Näringsliv. Retrieved from: http://www.realtid.se/ArticlePages/200711/16/20071116143956_Realtid157/20071116143956_Realtid157.dbp.asp (English translation: SEB buys a bank in Ukraine.)

Rekrut, S. (2013, January 1)._What is making foreigners to sell Ukrainian banks for \$1? Credit rating agency of Ukraine. Retrieved from: http://www.credit-rating.ua/en/analytics/opinion/13282/

Reuters (2014, February 26). 3-Russia's largest banks halt new loans in Ukraine eyeing political risk. Retrieved from: http://www.reuters.com/article/ukraine-crisis-idUSL6N0LV40J20140226

Rolander, D. (2009). Ukraina svider för Swedbank. Aktiespararen, 10. Retrieved from: http://www.aktiespararna.se/analys_swedbank0910 (English translation: Ukraine hurts Swedbank.)

RT News (2015, March 15). Ukraine's fourth largest lender Delta Bank insolvent - national bank. Retrieved from: https://www.rt.com/business/237161-ukraine-nbu-deltabank-bankruptcy/

Sveriges Riksbank (2006). Finansiell stabilitet 2006:1 and 2006:2. Retrieved from: http://www.riksbank.se/sv/Press-ochpublicerat/Publicerat-fran-Riksbanken/Finansiell-stabilitet/Rapporten-Finansiell-stabilitet/2006/ (English translation: Financial stability 2006:1 and 2006:2.)

Swedbank AB. Retrieved from: http://www.swedbank.com: Swedbank, Annual report 2002

Swedbank, Annual report 2005

Swedbank, Annual report 2007

Swedbank, Annual report 2008

Swedbank, Annual report 2009

Swedbank, Annual report 2010

Swedbank, Annual report 2012

Swedbank, Annual report 2013

Swedbank, Annual report 2014

Swedbank, press-release, 2007, February 7

Swedbank, press-release, 2007, July 9

Swedbank, press-release, 2008, October 7

Swedbank, press-release, 2009, April 29

Swedbank, press-release, 2013, April 1 
Tidningarnas Telegrambyrå (2007, February 7). Swedbank köper ukrainska TAS. Dagens industri. Retrieved from: http://www.di.se/artiklar/2007/2/7/swedbank-koper-ukrainska-tas/ (English translation: Swedbank buys Ukrainian TAS.)

Tigipko, S. (2008, March 5). Presentation during Capital market days. Retrieved from: https://www.swedbank.com/idc/groups/public/@i/@sbg/@gs/@ir/documents/presentation/cid_007052.pdf

USAID (United States Agency International Development) (2010). A Review and Assessment of the Ukrainian Financial Sector. Retrieved from: https://www.usaid.gov.

Vavryshchuk, V. (2010, June 15). Slow and Steady Wins the Race. Ukrainian Banks Initiating Coverage, BG Capital Research. Retrieved from: http://bgcapital.ge/img/st_img/researches/2010/BGC\%20Ukrainian\%20Banks\%20Initiating\%20Coverage\%20Jun15\% 202010.pdf

Waltersson, L. (2009, October 26). Swedbanks presidentkandidat: Vi måste koncentrera makten. Nyhetsportalen. Retrieved from: http://www.lasarnasfria.se/artikel/109231 (English translation: Swedbank's candidate for President: we must concentrate the power.)

Zelenyuk, V. (2007). The Ukrainian Stock Market. Beyond Transition Newsletter, the World Bank's Europe and Central Asia Department. Retrieved from: http://web.worldbank.org/WBSITE/EXTERNAL/NEWSLETTERS/EXTTRANSITION/EXTDECBEYTRANEWLET/ 0,,contentMDK:21491843 pagePK:64168445 piPK:64168309 theSitePK:1542353,00.html

\section{FURTHER READINGS AVAILABLE THROUGH INTERNET}

Deloitte (2011). Banking and insurance in Ukraine. Industry overview. Report. http://www.investin.if.ua/doc/pub/Overview_Banking-and-insurance_WWW.pdf

Government of Ukraine portal (2014, August 11). Foreign banks in Ukraine. Expectations and reality. Retrieved from: http://about-ukraine.net/foreign-banks-in-ukraine-expectations-and-reality.html

Invest in Ukraine. Retrieved from: http://www.investukraine.net/

OECD (2011). Ukraine. Investment Policy Reviews. Retrieved from: http://www.oecd-ilibrary.org/finance-and-investment/oecdinvestment-policy-reviews-ukraine-2011_9789264113503-en

PWC (PriceWaterhouseCoopers) (2013). Doing business and investing in Ukraine. Report. Retrieved from: https://www.pwc.com/ua/en/survey/2013/assets/ukraine_doingbusiness_2013.pdf

State Statistics Service of Ukraine http://www.ukrstat.gov.ua/

U.S. Department of State (2013). Investment Climate Statement - Ukraine. Bureau of Economic and Business Affairs, Report, February 2013. Retrieved from: http://www.state.gov/e/eb/rls/othr/ics/2013/204754.htm 


\section{DISCUSSION QUESTIONS}

1) Why transition economies became attractive for foreign investors after the fall of the Soviet Union? What were the main risks associated with FDI into transition economies?

2) Describe the investment environment of the host country (Sweden) and recipient country (Ukraine) in 2007, when the investment was made.

3) What were the main reasons for Swedbank to make FDI in Ukraine? Summarize the strategy of Swedbank in Ukraine.

4) What possible measures, in your view, could be done additionally to enhance governance and risk control of the subsidiary in Ukraine?

5) Describe the impact of financial crises on the Ukrainian market.

6) Describe and analyze exit strategy of Swedbank from the Ukrainian market. What additional measures can you suggest to improve the recovery of the loan portfolio and decrease losses?

7) What was the impact of this particular investment in Ukraine on the whole Swedbank Group?

8) What measures undertaken by the Swedish state, Swedbank's shareholders and management helped Swedbank to survive?

9) What type of measures have been suggested and undertaken by regulating authorities in order to improve financial stability in the society after financial crises 2008 ? Choose a country and elaborate the issue with application to the country of your choice.

10) What measures could improve the image of Ukraine for the foreign investors?

11) Find an example of successful and un-successful foreign investments abroad. Why some companies became successful while others failed?

12) How important is to view particular investment cases in the relevant institutional, economic, legal, political, social and cultural environments? Explain, based upon materials from the Case Study and from your own example.

13) Companies often face a dilemma: either to insure growth by accepting higher risks or to prioritize the lower risks at the expense of growth. What are the pros and cons of both strategies? Try to formulate your own recommendations on what risks companies, searching for growth, could accept and what risks they should strictly avoid.

14) Some researchers observe that certain opportunities are rooted outside the firm's relationships and networks. Opportunity creation is instead an outcome of discovery, luck and serendipity. Analyze this hypothesis in relationship with the presented Case Study and your own example.

15) Several authors who studied the process of decision-making suggested that changes in the turbulent and uncertain environment are bottom-up driven, emergent, and incremental, rather than formulated and implemented as assumed in the traditional strategic theory. Analyze bottom-up decision-making versus top down based upon empirical data from presented Case Study and your own example. 


\section{ENDNOTES}

${ }^{1}$ Translations of currencies in the Case are done according to following exchange rates: 1 SEK=0.129 USD (2014); 1 SEK=0.152 USD (2013); 1 SEK=0.153 USD (2012); 1 SEK=0.147 (2010); 1 SEK $=0.137$ (2009); $1 \mathrm{SEK}=0.128$ USD (2008); $1 \mathrm{SEK}=0.149$ USD (2007); $1 \mathrm{SEK}=0.146 \mathrm{USD}$ (2006); $1 \mathrm{USD}=0.79$ EUR (2006); 1 EUR=1.41 USD (2008).

As a reference, one Swedish crooner (SEK) is approximately 0.118951 USD as of 2016, February 4.

${ }^{2}$ See Corruption Perceptions Index http://www.transparency.org/cpi2015

${ }^{3}$ See http://www.nasdaqomxnordic.com/

${ }^{4}$ Business Sweden was founded on the first of January, 2013, by a merger of the Swedish Trade Council (Exportrådet) and Invest Sweden. Business Sweden is owned by the Swedish Government and the industry, a partnership that provides access to contacts and networks at all levels. Business Sweden has offices in nearly 50 of the world's markets. http://www.business-sweden.se/

${ }^{5}$ Risk-weighted asset is a bank's assets, weighted according to risk. Risk weights are used in determining the capital requirement or Capital Adequacy Ratio (CAR) for a financial institution. 